\title{
MEAT AND CARCASS CHARACTERISTICS OF GROWING PIGS FED MICROBIALLY ENHANCED CASSAVA PEEL DIETS
}

\author{
CARACTERÍSTICAS DE LA CARNE Y LA CANAL DE CERDOS EN CRECIMIENTO \\ ALIMENTADOS CON PELADURAS DE YUCA TRATADAS MICROBIALMENTE
}

\author{
Aro, S.O.* and Akinjokun, O.M. \\ Department of Animal Production and Health. Federal University of Technology. Akure. Nigeria. \\ *sambolaro@yahoo.co.uk
}

\section{AdDitionAl KEYWORDS}

Back fat. Dressing percentage. Microbial fermentation. Muscle protein.

\section{SUMMARY}

The proximate composition of meat and carcass characteristics of twenty-four (24) growing pigs fed graded levels of a microbially enhanced cassava peel diets were assessed in a trial that lasted three months. The cassava peels were fermented with a consortium of Aspergillus fumigatus (a fungus) and two lactic acid bacteria namely, Lactobacillus coryneformis and Lactobacillus delbrueckii, thus the fermented product was designated Microbially Enhanced Cassava Peel (MECP). The MECP was included in the ration formulation of the pigs at $0 \%, 20 \%, 40 \%$ and $60 \%$ levels. At slaughter, meat samples were collected from the M. biceps femoris to determine their proximate composition and the weights of the head, viscera and back fat thickness at the $1^{\text {st }}$ and $10^{\text {th }}$ ribs and $1^{\text {st }}$ lumbar vertebra were taken.

The results obtained revealed significant differences $(p<0.05)$ in proximate meat composition and carcass characteristics between animals fed on the control diet and those fed on varying levels of MECP diets. The treatment effect showed that animals raised on MECP with $60 \%$ level of inclusion had the highest $(15.09 \%)$ muscle protein. The female animals had significantly $(p<0.05)$ higher dry matter, ash, protein and fat content while the males had a higher moisture content in their $\mathrm{M}$. biceps femoris muscle. The sex versus treatment effect revealed the female animals on $60 \%$ MECP had the least $(69.21 \%)$ moisture content while the male animals on $40 \%$ MECP had the highest $(75.42 \%)$. Muscle protein was highest in animals fed $20 \%$ MECP while the female animals on $60 \%$

Recibido: 31-1-11. Aceptado: 23-2-12.

\section{Palabras clave adicionales}

Fermentación microbiana. Grasa dorsal. Proteína muscular. Rendimiento canal.

MECP had the highest (13.86\%) level of muscular fat. The female animals had thicker back fat at the $1^{\text {st }}$ and $10^{\text {th }}$ ribs and at the $1^{\text {st }}$ lumbar vertebra. Ash content of the muscle increased as the level of inclusion of MECP in the diets increased also animals fed MECP diets had the leanest carcasses.

It can be concluded that feeding pigs with $40 \%$ dietary level of MECP would ensure carcass leanness and improve protein and dry matter content of pig's meat.

\section{RESUMEN}

La composición de la carne y las características de la canal de 24 cerdos en crecimiento, alimentados con una dieta a base de peladuras de yuca mejoradas microbiológicamente fueron analizadas en un experimento que duró tres meses. Las peladuras de yuca fueron fermentadas con una asociación del hongo Aspergillus fumigatus y dos bacterias lácticas: Lactobacillus coryneformis y Lactobacillus delbrueckii. El producto fermentado fue denominado Peladuras de Yuca Microbiológicamente Mejoradas (MECP). EI MECP fue incluido en las raciones de los cerdos a las proporciones de $0 \%, 20 \%, 40 \%$ y $60 \%$. En el momento del sacrificio fueron obtenidas muestras del Musculus biceps femoris para determinar su composición así como los pesos de cabeza, vísceras y espesor de la grasa dorsal a la altura de las $1^{\mathrm{a}}$ y $10^{\mathrm{a}}$ costillas y $1^{\mathrm{a}}$ vértebra lumbar.

Los resultados obtenidos revelaron diferencias significativas $(p<0,05)$ en la composición de 


\section{ARO AND AKINJOKUN}

la carne y características de la canal entre los animales control y los alimentados con MECP. El efecto de los tratamientos demostró que los animales alimentados con $60 \%$ de MECP alcanzaron el mayor nivel de proteína muscular (15,09\%). Las hembras, tuvieron mayor $(p<0,05)$ concentración de materia seca, cenizas, proteína y grasas, mientras que los machos tenían mayor contenido de humedad en el Biceps femoris. El efecto del sexo vs. tratamiento puso de manifiesto que las hembras con $60 \%$ de MECP tienen el menor contenido de humedad $(69,21 \%)$ mientras que los machos con $40 \%$ MECP tuvieron el contenido más alto $(75,42 \%)$. La proteína muscular fue más elevada en los animales alimentados con $20 \%$ de MECP, mientras que las hembras alimentadas con $60 \%$ MECP tuvieron el nivel más alto de grasa muscular (13,86\%). Las hembras tuvieron mayor grosor de la grasa dorsal a la altura de las $1^{\mathrm{a}}$ y $10^{\mathrm{a}}$ costillas y $1^{\text {a }}$ vértebra lumbar. La concentración de cenizas en el músculo aumentó con el nivel de inclusión de MECP en la dieta. También los animales consumiendo dietas con MECP mostraron canales más magras. Puede concluirse que la alimentación de cerdos con un $40 \%$ de MECP en la dieta, asegura canales magras y mejora el nivel de proteína y materia seca de la carne de cerdo.

\section{INTRODUCTION}

As a palliative to the high cost of conventional feed ingredients, many unconventional feed sources have been tried by researchers to reduce feed cost and ensure the profitability of the livestock enterprise especially in developing countries where scarcity of the conventional ingredients is a perennial problem (Onimisi and Omage, 2006; Owen et al., 2009). Many of these unconventional ingredients are agroindustrial by-products of such crops like rice, maize, groundnut, soybean, oil palm and cassava. Recently in Nigeria, the government legislated in favour of the use of $10 \%$ cassava flour in the pastry and confectionery industry as a way of encouraging the production and utilization of cassava products in the country. Many cassava flour processing plants thus sprang up to take advantage of this initiative by the government. The attendant effect of this is the huge quantity of cassava tuber wastes that are being discharged into the environment on a daily basis (Aro et al., 2010b). These agro-industrial by-products have the potentials of being utilized as alternative feed ingredients but are however constrained by low protein content, high fibre content and high levels of feed antinutrients (D'Mello, 1995; Udedibie et al., 2004). Efforts have been made to enhance the utilization of these wastes in livestock ration through many nutrient-enhancing methods (Aro et al., 2009; Aro et al., 2010a).

The potential use of these unconventional feed ingredients has often been measured by performance indicators like weight gain, feed conversion ratio, feed efficiency and feed cost/kilogramme weight gain. Of much importance to the health and sensory appeal of the consumers of animal products on one hand and the producers of the products on the other hand are such carcass indices like fat content, protein content, carcass yield and the lean to fat ratio of the carcass of animals fed with these unconventional feed ingredients. For instance, Sarker et al. (2010) reported that besides human consumption, the low grade green tea and green tea wastes (unconventional feed ingredients from tea) were used as feed ingredients for fish, broiler, calves and pigs. These authors showed that pigs fed graded levels of green tea in their diets had thinner back fat, higher protein and moisture and lower crude fat in their carcasses. Isah et al. (2009) also reported an increased level of crude protein and a decrease in fat content of the Longissimus dorsi muscle of West African Dwarf(WAD) goats fed slaughter house by-products. The effect of dietary replacement of fish meal with dried poultry waste in broilers diets was investigated by Oke et al. (2010) with a conclusion that dietary poultry waste resulted in better carcass weight of the choice regions like the breast and drumstick and suggested that half of the required fish 
meal by broilers could be replaced with dried poultry dropping meal.

The effect of the use of fermented sweet orange peel on carcass quality of broilers was investigated by Oluremi et al. (2010). These authors reported a significant effect on the birds dressing percentage and concluded that $30 \%$ replacement of maize with naturally fermented sweet orange peel meal is practicable in broiler production enterprise. Fermented cassava products have also been used severally as alternative feed sources for many livestock species with cost-reducing benefits (Udedibie et al., 2004; Ekpo et al., 2009). There is however little information on the effects of the use of microbially fermented cassava wastes on meat quality and carcass characteristics of farm animals and especially of pigs. The objective of this research work was to investigate the effect of feeding cassava peels fermented with candidate organisms on proximate meat composition and carcass characteristics of pigs.

\section{MATERIALAND METHODS}

Twenty-four cross-bred pigs (Large White $x$ Duroc) with an average initial weight of $31.23 \mathrm{~kg}$ were used to study the effects of graded levels of microbially enhanced cassava peels (MECP) on proximate meat composition and carcass characteristics. The MECP were prepared according to the methods described by Aro et al. (2008). Briefly: the cassava peels were sundried for three to five days depending on environmental temperature and the intensity of the sun. They were thereafter crushed to aid further processing, packed and stored in a cool place prior to inoculation with microorganisms. Two different strains of lactic acid bacteria (Lactobacillus delbrueckii and Lactobacillus coryneformis) and a fungus (Aspergillus fumigatus) were isolated and cultured at the Department of Microbiology, Federal University of Technology, Akure. Two kilogrammes (2 $\mathrm{kg}$ ) of dried cassava peels were weighed into nylon bags and $1500 \mathrm{~mL}$ of sterile water were added. The samples were then steamheated for 30 minutes at $100^{\circ} \mathrm{C}$. The samples were allowed to cool after which they were emptied into fermentation trays overlaid with cellophane wrapper inside the lamina flow chamber. Each $2 \mathrm{~kg}$ sample was then inoculated with $15 \mathrm{~mL}$ each of L. delbrueckii and L. coryneformis containing $1.02 \times 10^{4}$ cells $/ \mathrm{mL}$, and $30 \mathrm{~mL}$ of Aspergillus fumigatus containing $1.07 \times 10^{7}$ spores $/ \mathrm{mL}$. The trays were then covered with cellophane wrapper and kept in fermentation chamber for five days under ambient temperature and controlled humidity ensured by the cellophane wrapper technique meant to maintain optimum water activity (figures 1 and 2). After the fifth day, the samples were harvested and sundried for three or more days prior to their incorporation into the diets of the pigs.

Four pigs' growers' diets were formulated in which the MECP meal was incorporated at $0 \%, 20 \%, 40 \%$ and $60 \%$ levels (table I). The pigs were randomly allotted to these four treatment diets at six animals (three males and three females) per treatment with each animal serving as a replicate of its treatment group. The animals were housed in individual pens measuring $2 \times 3$ m each fitted with a concretized feeding and drinking trough. Feeding was at $5 \%$ of the pigs' body weight which was adjusted weekly to reflect change in weight while water was given ad libitum throughout twelve week duration of the experiment. At the end of the twelfth week, the animal were starved of feed overnight, weighed and taken to the slaughter slab at 07 hours the following morning where they were stunned, bled, scalded, de-haired and dressed. The biceps femoris was neatly dissected from the right thigh musculature of the warm carcass of each animal from which $20 \mathrm{~g}$ samples were taken for proximate analysis. Measurement of the back fat thickness was taken (with a flexible measuring tape graduated to $1 \mathrm{~mm}$ ) at the 


\section{ARO AND AKINJOKUN}

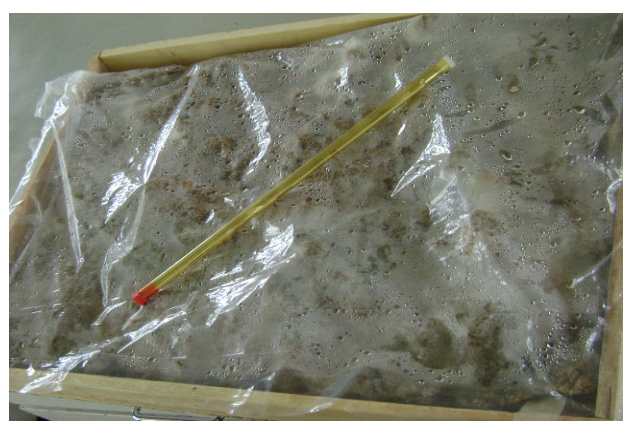

Figure 1. A fermentation tray with the cellophane wrapper that ensures optimum water activity within the fermenting substrates. Visible are the refluxing water droplets. (Una bandeja de fermentación con la envuelta de celofán que asegura una óptima actividad del agua dentro de los sustratos en fermentación. Son visibles las gotas de agua de condensación).

first rib, tenth rib and at the first lumbar vertebra. Proximate analyses were carried out for moisture, crude protein, ether extract and ash of the meat samples as described by the methods of AOAC (1996). Data obtained on the proximate composition of the muscle and carcass parameters were subjected statistical analysis using the SAS (2000)

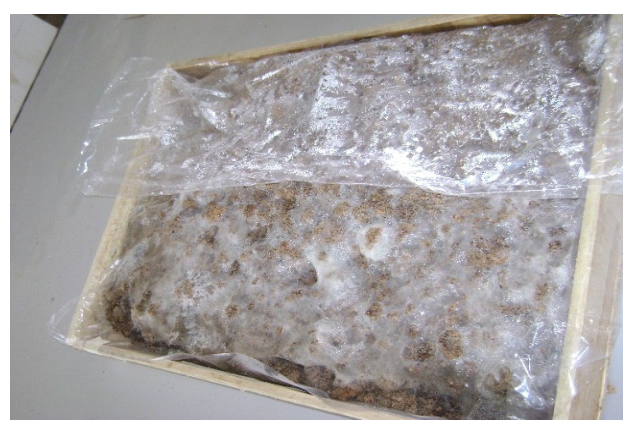

Figure 2. The cellophane wrapper partly exposed to show the extent of mycelial growth after five days offermentation. (El envoltorio de celofán, parcialmente retirado para mostrar el crecimiento miceliano después de cinco dias de fermentación).
Table I. Gross composition (\%) of the experimental diets. (Composición (\%) de las dietas experimentales).

\begin{tabular}{lcccc}
\hline MECP & $0 \%$ & $20 \%$ & $40 \%$ & $60 \%$ \\
\hline Maize & 40.00 & 35.00 & 15.00 & 0.00 \\
Rice bran & 11.00 & 7.20 & 10.00 & 0.00 \\
PKC & 26.50 & 16.50 & 14.50 & 21.30 \\
GC & 17.00 & 18.30 & 17.50 & 15.70 \\
MECP & - & 20.00 & 40.00 & 60.00 \\
VO & 2.50 & - & - & - \\
BM & 1.50 & 1.50 & 1.50 & 1.50 \\
OS & 0.50 & 0.50 & 0.50 & 0.50 \\
Premix vit/min & 0.50 & 0.50 & 0.50 & 0.50 \\
Salt & 0.50 & 0.50 & 0.50 & 0.50 \\
Total & 100.00 & 100.00 & 100.00 & 100.00 \\
CP & 18.07 & 18.09 & 18.09 & 18.04 \\
ME & 3022.8 & 3012.3 & 3015.7 & 3003.2 \\
\hline
\end{tabular}

$\mathrm{MECP}=$ Microbially enhanced cassava peel; $\mathrm{PKC}=$ Palm kernel cake. $\mathrm{GC}=$ Groundnut cake; $\mathrm{VO}=$ Vegetable oil; $\mathrm{BM}=$ Bone meal; OS= Oyster shell; $\mathrm{CP}=$ Crude protein; $\mathrm{ME}=$ Metabolizable energy (kcal/kg).

statistical package. Mean separation where applicable was done with the same statistical package.

\section{RESULTSANDDISCUSSION}

Table II shows the proximate analysis of the biceps femoris muscle (fresh weight basis) taken from the experimental animals. The effect of sex showed that fat, protein, ash and dry matter were higher in the female than in the male pigs while the males had higher moisture content. The treatment effect revealed that animals fed $40 \%$ MECP had highest ash and moisture but with the lowest fat content while the highest dry matter, protein and fat were observed in the animals fed $60 \%$ MECP. Generally, ash and protein were improved by the dietary inclusion of MECP. Sex versus treatment effect showed that female animals on $40 \%$ MECP had more mineralization $(4.81 \%)$ and less lipogenesis $(8.34 \%)$ of their musculature while their male

Archivos de zootecnia vol. 61, núm. 235, p. 410. 
Table II. Least square means of proximate composition of meat samples (fresh weight basis) of pigs fed varying levels of microbially enhanced cassava peel diets. (Medias cuadráticas mínimas (sobre peso fresco) de la composición de muestras de carne de cerdos alimentados con niveles variables de peladuras de yuca microbiológicamente mejoradas).

\begin{tabular}{lcccccc}
\hline $\begin{array}{l}\text { Source } \\
\text { of variation }\end{array}$ & $\begin{array}{c}\text { Animals } \\
\text { Sex }\end{array}$ & $\begin{array}{c}\text { Moisture } \\
\%\end{array}$ & $\begin{array}{c}\text { Dry matter } \\
\%\end{array}$ & $\begin{array}{c}\text { Ash } \\
\%\end{array}$ & $\begin{array}{c}\text { Crude protein } \\
\%\end{array}$ & $\begin{array}{c}\text { Ether extract } \\
\%\end{array}$ \\
\hline Male & 12 & $74.42 \pm 0.68^{\mathrm{a}}$ & $25.58 \pm 0.68^{\mathrm{b}}$ & $3.01 \pm 0.39^{\mathrm{b}}$ & $13.88 \pm 0.72^{\mathrm{b}}$ & $8.70 \pm 0.92^{\mathrm{b}}$ \\
Female & 12 & $71.01 \pm 1.35^{\mathrm{b}}$ & $28.99 \pm 1.35^{\mathrm{a}}$ & $3.95 \pm 0.27^{\mathrm{a}}$ & $15.01 \pm 0.70^{\mathrm{a}}$ & $10.03 \pm 0.71^{\mathrm{a}}$ \\
Treatment & & & & & & \\
$\quad 1,0 \%$ MECP & 6 & $73.02 \pm 0.54^{\mathrm{a}}$ & $27.00 \pm 0.54^{\mathrm{b}}$ & $2.63 \pm 0.20^{\mathrm{d}}$ & $13.82 \pm 0.76$ & $10.55 \pm 0.57^{\mathrm{a}}$ \\
$2,20 \%$ MECP & 6 & $73.31 \pm 1.08^{\mathrm{a}}$ & $26.69 \pm 1.08^{\mathrm{b}}$ & $3.76 \pm 0.53^{\mathrm{b}}$ & $14.56 \pm 1.38$ & $8.38 \pm 1.15^{\mathrm{b}}$ \\
$3,40 \%$ MECP & 6 & $73.60 \pm 1.26^{\mathrm{a}}$ & $26.40 \pm 1.26^{\mathrm{b}}$ & $4.29 \pm 0.40^{\mathrm{a}}$ & $14.32 \pm 1.27$ & $7.80 \pm 0.99^{\mathrm{b}}$ \\
$4,60 \%$ MECP & 6 & $72.28 \pm 2.87^{\mathrm{b}}$ & $29.06 \pm 2.87^{\mathrm{a}}$ & $3.25 \pm 0.60^{\mathrm{c}}$ & $15.09 \pm 0.65$ & $10.72 \pm 1.20^{\mathrm{a}}$ \\
Sex ${ }^{\star}$ treatment & & & & & & \\
$\quad$ Male-1 & 3 & $72.94 \pm 0.30^{\mathrm{b}}$ & $27.06 \pm 0.30^{\mathrm{b}}$ & $2.21 \pm 0.14^{\mathrm{c}}$ & $13.25 \pm 1.59$ & $11.60 \pm 2.64^{\mathrm{a}}$ \\
Male-2 & 3 & $73.96 \pm 2.29^{\mathrm{a}}$ & $26.04 \pm 2.29^{\mathrm{c}}$ & $4.11 \pm 0.99^{\mathrm{a}}$ & $13.57 \pm 1.55$ & $8.36 \pm 1.57^{\mathrm{b}}$ \\
Male-3 & 3 & $75.42 \pm 1.54^{\mathrm{a}}$ & $24.58 \pm 1.54^{\mathrm{d}}$ & $3.76 \pm 0.64^{\mathrm{a}}$ & $13.57 \pm 2.24$ & $7.25 \pm 1.57^{\mathrm{b}}$ \\
Male-4 & 3 & $75.35 \pm 0.49^{\mathrm{a}}$ & $24.65 \pm 0.49^{\mathrm{d}}$ & $1.94 \pm 0.25^{\mathrm{c}}$ & $15.14 \pm 0.59$ & $7.58 \pm 1.85^{\mathrm{b}}$ \\
Female-1 & 3 & $73.06 \pm 1.17^{\mathrm{a}}$ & $26.94 \pm 1.17^{\mathrm{c}}$ & $3.05 \pm 0.11^{\mathrm{b}}$ & $14.38 \pm 0.22$ & $9.51 \pm 2.30^{\mathrm{b}}$ \\
Female-2 & 3 & $72.66 \pm 0.47^{\mathrm{a}}$ & $27.34 \pm 0.47^{\mathrm{b}}$ & $3.40 \pm 0.55^{\mathrm{b}}$ & $15.55 \pm 2.47$ & $8.40 \pm 1.24^{\mathrm{b}}$ \\
Female-3 & 3 & $71.78 \pm 1.52^{\mathrm{b}}$ & $28.22 \pm 1.52^{\mathrm{b}}$ & $4.81 \pm 0.34^{\mathrm{a}}$ & $15.07 \pm 1.58$ & $8.34 \pm 1.43^{\mathrm{b}}$ \\
Female-4 & 3 & $69.21 \pm 5.62^{\mathrm{c}}$ & $30.79 \pm 5.62^{\mathrm{a}}$ & $4.55 \pm 0.08^{\mathrm{a}}$ & $15.05 \pm 1.33$ & $11.19 \pm 0.71^{\mathrm{a}}$ \\
\hline
\end{tabular}

abcdMeans on the same column but with different superscripts are statistically $(p<0.05)$ significant.

counterparts had the least $(7.25 \%)$ fat and the highest $(75.42 \%)$ moisture content. Sarker et al. (2010), working on an unconventional feed ingredient: green tea, reported decreased lipogenesis, increased protein accretion and decrease in ash content of the muscle in pigs fed dietary inclusion of green tea. The increase in ash content of the muscle in this study could have been caused by the process of fermentation which the cassava peels underwent with improved mineralization of the fermented product (MECP) which ultimately furnish more minerals that are incorporated into the tissue upon absorption. The moisture content of the muscle increased with dietary inclusion of MECP in the males while it decreased in the females. Protein increased progressively in muscle of the male animals in relation to increase in the levels of dietary MECP. In the female, it increased initially at $20 \% \mathrm{MECP}$ level from where it declined but with numerical values still higher than that of the control diet. Sarker et al. (2010) obtained similar trend with dietary green tea with pigs whose muscle protein initially increased but later decline at $2 \%$ inclusion level. The dry matter content of the muscle in the female animals also increased progressively from $20 \%$ MECP to $60 \%$ MECP while in the males the ash content improved from $20 \%$ MECP but decline below the value of the control treatment at $60 \%$ MECP level.

The carcass parameters of pigs fed varying levels of MECP are as shown in table III. Observation on the effect of sex showed that the female animals had numerically heavier slaughter weight, deeper back fat, heavier head and heavier weight of the viscera organs but lower dressing percentage. The dressing percentage values however compared with literature values on 


\section{ARO AND AKINJOKUN}

Table III. Least square means of carcass parameters of pigs fed varying levels of microbially enhanced cassava peel diets. (Medias mínimas cuadráticas para los parámetros de la canal de cerdos alimentados con niveles variables de peladuras de yuca microbiológicamente mejoradas).

\begin{tabular}{|c|c|c|c|c|c|c|c|}
\hline Sou & & & & & $\mathrm{Ba}$ & fat thickness & $\mathrm{s}(\mathrm{cm})$ \\
\hline $\begin{array}{l}\text { of variation } \\
\left.\text { ( } \mathrm{n}^{\circ} \text { animals }\right)\end{array}$ & & & & & $1^{\text {st }}$ rib & $10^{\text {th }}$ rib & $1^{\text {st }}$ lumb \\
\hline Sex & & & & & & & \\
\hline ale $(1$ & $68.08 \pm$ & $6.66 \pm$ & 11.6 & $4^{\mathrm{a}}$ & $2.20 \pm 0$ & 1.50 & 0.8 \\
\hline male (12) & $70.50 \pm$ & 7.40 & $11 . c$ & 72. & $2.95=$ & 2.0 & 1. \\
\hline (6) & & & & & & & \\
\hline $1,0^{\circ}$ & $76.67 \pm$ & 7.83 & 13. & & 2. & $0^{a}$ & \\
\hline & 58.00 & & & & & & \\
\hline & 75 & & & & & & \\
\hline$+60 \%$ & 54.67 & $6.07 \pm$ & $9.8-r-1$ & 70. & $2.00 \pm$ & 1.00 & 0.6 \\
\hline & & & & & & & \\
\hline $1-\Lambda$ & $69.00 \pm 1$ & 7.50 & 12.8 & 70 & $2.75=$ & & \\
\hline & $92.12 \pm$ & $8.50 t$ & 15.8 & 73.50 & $3.00 \pm$ & 2.96 & 2.9 \\
\hline & 58.1 & $6.08=$ & 10.80 & 70.96 & $2.50 \pm 0$ & 1.90 & 1.6 \\
\hline & 58.5 & 6.30 & 10.50 & 71.30 & $2.80 \pm($ & 2.68 & 1.00 \\
\hline & 72 & 7.40 & 13.1 & 72.27 & $2.05 \pm 0.62^{b}$ & 0.80 & 0.7 \\
\hline $3-$ & 78.6 & 7.90 & 11.30 & 75.59 & $3.00 \pm 0.73^{a}$ & $1.50 \pm$ & $1.00 \pm 0.27^{\circ}$ \\
\hline 4-Male & $55.53 \pm 3.29^{b}$ & $5.65 \pm 0.77^{b}$ & $9.73 \pm 2.14^{c}$ & $72.30 \pm 1.33^{b}$ & $1.50 \pm 0.61^{\mathrm{b}}$ & $1.00 \pm 0.58^{c}$ & $0.50 \pm 0.13^{c}$ \\
\hline 4-Female & $54.38 \pm 6.32^{\mathrm{c}}$ & $6.90 \pm 0.78^{b}$ & $10.12 \pm 1.44^{\mathrm{c}}$ & $68.92 \pm 4.56^{d}$ & $3.00 \pm 0.74^{a}$ & $1.00 \pm 0.48^{c}$ & $0.80 \pm 0.12^{c}$ \\
\hline
\end{tabular}

abcdMeans on the same column with different superscripts are statistically $(p<0.05)$ different.

growing pigs (Estany et al., 2002; Carr et al., 2005; Matthews et al., 2005). The values obtained for back fat thickness at the $1^{\text {st }}$ rib between the sexes were lower than 3.51-4.00 $\mathrm{cm}$ reported by Carr et al. (2005) and this showed that the animals under this study were leaner. The back fat thickness at the $10^{\text {th }}$ rib obtained in this study was slightly higher than between $1.49 \mathrm{~cm}$ to $1.54 \mathrm{~cm}$ reported by Matthew et al. (2005) but compared with $1.58 \mathrm{~cm}$ to $2.07 \mathrm{~cm}$ reported by Carr et al. (2005). The effect of dietary treatments on carcass parameters revealed that the best dressing percentage was observed in animals fed $40 \%$ dietary inclusion of MECP. There was a corresponding improvement in carcass leanness as the level of MECP increased in the diets as reflected in the values of back fat thickness at the $1^{\text {st }}$ and $10^{\text {th }}$ rib and the $1^{\text {st }}$ lumbar vertebra. The effect of sex versus treatment showed that the male animals on $40 \%$ MECP had the heaviest $(74.12 \mathrm{~kg})$ slaughter weight among the male animals while the female animals on $0 \% \mathrm{MECP}$ had the heaviest $(92.12 \mathrm{~kg})$. Dressing percentage increased with increasing levels of MECP among the males while the $40 \%$ MECP level recorded the best dressing percentage $(75.59 \%)$ in both sexes.

\section{CONCLUSION}

This study revealed potential benefits that could be harnessed through the use of microbially enhanced cassava peel (MECP) in terms of meeting the demand of consumers for carcass leanness especially among those watching their weights and those at risk of hypercholesterolaemia and hyperlipaemia. The higher dressing percentage recorded in 


\section{MEAT AND CARCASS OF PIGS FED MICROBIALLY ENHANCED CASSAVA PEEL DIETS}

pigs fed with $40 \%$ MECP diet would also indicate more saleable cuts per kilogramme carcass weight upon slaughter. The consumers would also benefit from more protein and mineral contents of the meat.

\section{REFERENCES}

AOAC. 1996. Association of Official Analytical Chemists. Official methods of analysis. Horwitz, W., Ed. $18^{\text {th }}$ ed. Washington DC. USA.

Aro, S.O., Aletor, V.A., Tewe, O.O., Fajemisin, A.N., Usifo, B. and Falowo, A.B. 2008. Preliminary investigation on the nutrients, anti-nutrients and mineral composition of microbially fermented cassava starch residues. Proc. $33^{\text {rd }}$ Annu. Conf., Nig. Soc. for Anim. Prod. Olabisi Onabanjo Univ. Ayetoro. Ogun State, Nigeria. March 17-20. pp. 248-251.

Aro, S.O., Aletor, V.A., Adebayo, I.A., Oladunmoye, M.K., Oboh, G. and Usifo, B. 2009. Performance and nutrient digestibility of growing pigs fed dietary inclusion of differently fermented cassava tuber wastes. Proc. $34^{\text {th }}$ Annu. Conf., Nig. Soc. for Anim. Prod. 15-18 March. Univ. of Uyo. Nigeria. pp. 450-453.

Aro, S.O., Aletor, V.A. and Ajepe, O.A. 2010a. Comparative study of nutrient enhancement of cassava starch residues fermented naturally and by microbial inoculation. Proc. $35^{\text {th }}$ Annu. Conf., Nig. Soc. for Anim. Prod. 14-17 March. Univ. of Ibadan. Nigeria. pp. 779-782.

Aro, S.O., Aletor, V.A., Tewe, O.O. and Agbede, J.O. 2010b. Nutritional potentials of cassava tuber wastes: A case study of a cassava starch processing factory in south-western Nigeria. Livest Res Rural Develop, 22, Article \#213. http://www.Irrd.org//rrd22/11/aro22213. htm (01/09/2011).

Carr, S.N., Roncker, P.J., Killifer, J., Baker, D.H., Ellis, M. and McKeith, F.K. 2005. Effects of different cereal grains and ractopamine hydrochloride on performance, carcass characteristics and fat quality in late finishing pigs. J Anim Sci, 83: 223-230.

D'Mello, J.P.F. 1995. Anti-nutritional factors in legume seeds. In: J.P.F. D'Mello and C. Devendra (Eds.). Tropical legumes in animal nutrition. CAB, International. Wallingford, UK. pp. 135-172.

Ekpo, J.S., Udedibie, A.B.I. and Asuquo, L.E. 2009.
The utilisation of MECP at $40 \%$ level is recommended for optimal effects in terms of higher dressing percentage and proximate meat composition as far as this trial is concerned.

Replacement value of a mixture of cassava tuber meal, brewers dried grains and palm oil for maize in the diets of young growing pigs. Proc. $34^{\text {th }}$ Annu. Conf., Nig. Soc. for Anim. Prod. 1518 March. Univ. of Uyo. Nigeria.

Estany, J., Villalba, D., Tor, M., Cubilo, D. and Noguera, J.L. 2002. Correlated response to selection for litter size in pigs: II. Carcass, meat and fat quality traits. J Anim Sci, 80: 2566-2573.

Matthews, J.O., Guzic, A.C., LeMieux, F.M., Southern, L.L. and Bidner, T.D. 2005. Effects of chromium propionate on growth, carcass traits and pork quality of growing-finishing pigs. $J$ Anim Sci, 83: 858-862.

Oke, D.B., Oke, M.O. and Oyeniyi, F.G. 2010. Effect of Methionine and Lysine supplementation on the carcass quality of finisher broilers fed dried layers dropping meal as replacement for fish meal. Proc. $35^{\text {th }}$ Annu. Conf., Nig. Soc. for Anim. Prod. 14-17 March. Univ. of Ibadan. Nigeria. pp. 443-445.

Oluremi, O.I.A., Ebe, A.I., Ngi, J. and Aku, E.O. 2010. Effect of naturally fermented sweet orange (Citrus sinensis) peel meal on its maize replacement valuein broiler diet on performance and carcass indices. Proc. $35^{\text {th }}$ Annu. Conf., Nig. Soc. for Anim. Prod. 14-17 March. Univ. of Ibadan. Nigeria. pp. 449-542.

Isah, O.A., Abieyuwa, O. and Akinsoyinu, O.A. 2009. Performance, linear body measurement and carcass characteristics of West African Dwarf (WAD) goats fed diets supplemented with slaughter house by-products. Nig J Anim Prod, 36: 113-124.

Onimisi, P.A. and Omage, J.J. 2006. Evaluation of poultry litter as feedstuff for growing rabbits. Livest Res Rural Develop, 18: 5-10.

Owen, J.O., Amakiri, A.O. and Ngodigha, E.M. 2009. Physiological responses of weaner rabbits fed graded levels of poultry litter. Proc. $34^{\text {th }}$ Annu. Conf., Nig. Soc. for Anim. Prod. 1518 March. Univ. of Uyo. Nigeria. pp. 214-218. 


\section{ARO AND AKINJOKUN}

SAS. 2000. Users' Guide: Statistical analysis systems. Institute Inc. Cary. North Carolina, USA. Sarker, S.M.K., Yim, K.J., Ko, S.Y., Uuganbayar, D., Kim, G.M., Bae, I.H., Oh, J.I., Yee, S.T. and Yang, C.J. 2010. Green tea level on growth performance and meat quality in finishing pigs.
Pakistan J Nutrition, 9: 10-14.

Udedibie, A.B.I., Anyaegbu, B.C., Onyechekwa, G.C. and Egbuokporo, O.C. 2004. Effects of feeding different levels of fermented and unfermented cassava tuber meals on performance of broilers. Nig J Anim Prod, 31: 211-219. 